\title{
Health Education for the Prevention of Covid-19 Transmission with the 3M Movement in Ngaglik District, Batu City, East Java
}

\author{
Santy Irene Putri ${ }^{1}$, Aris Widiyanto ${ }^{2}$, Asruria Sani Fajriah ${ }^{3 *}$, Joko Tri Atmojo ${ }^{4}$, \\ Prima Soultoni Akbar ${ }^{5}$, Nur Laili Qomariah' \\ ${ }^{1}$ Universitas Tribhuwana Tunggadewi Malang, ${ }^{2,4}$ High School of Health Sciences Mamba'ul 'Ulum \\ Surakarta, Indonesia, ${ }^{3}$ Institute of Health Sciences Strada Indonesia, Kediri, ${ }^{5}$ Politeknik Kesehatan \\ Kemenkes Malang, ${ }^{6}$ Universitas Sebelas Maret Surakarta \\ *Email: sanifajriah@gmail.com
}

\begin{abstract}
Background: WHO has officially decided Covid-19 as a pandemic. The Indonesian government has designated Covid-19 as a non-natural disaster in the form of a disease outbreak that needs to be addressed systematically in various ways, including involving all community members. In terms of the transmission pattern of Covid-19, which has spread in almost all regions of the province of Indonesia, the number of cases and the number of deaths is increasing every day and has an impact on health, political, social, economic, cultural and other aspects. Preventive action is a strategy to reduce the spread of Covid-19. The aim of this community service is that after receiving health education, people are aware the most important strategy is to use a mask, wash your hands and / or use a portable hand sanitizer (handsanitazier). Avoid touching their face and mouth after interacting with a potentially contaminated environment and keeping a distance from other people. Methods: Health education is carried out through lectures and discussions with the community using LCD media as well as leaflet distribution and distribution of masks by complying with health protocols such as participants using masks, maintaining distance and providing outdoor hand washing stations. The implementation of the activity begins with a pre-test, and ends with post-test measurements.The activity was carried out on January 2, 2021 with the target of all members of the community in Ngaglik District, Batu City, East Java. Results: As many as 20 participants were involved in the implementation of health education activities for the prevention of covid-19 transmission with the $3 M$ movement. The activity can be carried out smoothly, the participants are enthusiastic and understand the material that has been delivered, it is proven when the presenter carries out the evaluation that the participants are able to answer the questions given well. Conclusion: health education activities for the prevention of covid-19 transmission with the 3M movement are effective in increasing public health insights and knowledge, creating public awareness to implement the $3 M$ movement and self-awareness to adopt a clean and healthy lifestyle.
\end{abstract}

Keywords: behavior; covid-19; health education; healthy life style; knowledge; mask; preventive

\section{INTRODUCTION}

Coronavirus Disease 2019 (COVID-19) is an infectious disease caused by the Savere Acute Respiratory Syndrome Coronavirus 2 (SARS-Cov-2). SARS-Cov-2 is a new type of coronavirus not previously found in humans. There are two types of coronavirus that are known to cause diseases that can trigger severe symptoms, such as Middle East Repiratory Syndrome (MERS) and Severe Acute Respiratory Syndrome (SARS). The clinical presentation of Covid-19 infection ranges from pneumonia without symptoms to being serious with acute respiratory distress syndrome, septic shock and multiple organ failure, which can lead to death (Guan et al., 2020).

On December 31, 2019, the World Health Organization (WHO) reported that there were cases of pneumonia with an unknown cause in Wuhan City, Hubei Province, China. On January 30, 2020, WHO stated that the Covid-19 virus was a public health emergency of international concern and on March 11, 2020, WHO officially decided Covid-19 as a pandemic (WHO, 2020). The Indonesian government has designated 
Covid-19 as a non-natural disaster in the form of a disease outbreak that needs to be handled in an integrated manner in various ways, including involving all the community's compartments.

The increase in the number of Covid-19 cases worldwide is quite fast, until now as of December 30, 2020 there were 628,996 new cases confirmed. In Indonesia, the total number of cases is 735,124 with the division of the five provinces that contributed the most to Covid-19 cases, namely DKI Jakarta, East Java, West Java, Central Java and South Sulawesi (WHO, 2020) (Kemenkes RI, 2020). In view of the pattern of the spread of Covid-19 which has occurred in almost all regions of the province of Indonesia with the number of cases and the number of deaths that are increasing day by day and have an impact on health, political, social, economic, cultural and other aspects (Kementrian RI, 2020b).

From these data cases of covid-19 infection are increasing every day, therefore it is hoped that with the existence of public health education activities, they can find out and be able to participate in efforts to prevent the spread and transmission of Covid-19 by means of the $3 \mathrm{M}$ movement (Wearing masks, Keeping distance, and Washing hand).

\section{LITERATURE REVIEW}

\section{Epidemiology}

Coronavirus Disease 2019 (Covid-19) is a contagious disease caused by a new type of Coronavirus. This disease began with the emergence of pneumonia of unknown ethylogy in Wuhan, a city in Hubei province, China at the end of 2019. On January 30, 2020, WHO declared the Cvovid-19 outbreak a public health emergency of international concern and in March 2020, it began characterize it as a pandemic to suppress the dire situation and urge all countries to take action to detect the infection and prevent its spread (Li et al., 2020).

Based on the results of the epidemiological study, the case is thought to be related to the Seafood Market in Wuhan. On January 7, 2020 the Chinese government finally announced that what caused the disease was a new type of Coronavirus which was later named SARS-Cov-2 (Severe Acute Respiratory Syndrome Coronavirus 2). The virus originates from different families, but SARS-CoV-2 has a higher transmission rate compared to SARS-CoV and MERS-CoV (Arima et al., 2020).

On March 2, 2020, the Indonesian state delivered the first case of Covid-19 and the number has continued to increase to date. As of December 30, 2020, the Ministry of Health reported 8,002 new cases. The Chinese CDC reported that the highest cases occurred in men $(51.4 \%)$ and most occurred at the age of $30-79$ years $(87 \%)$ and the lowest occurred at $<10$ years $(1 \%)$. As many as $81 \%$ of cases were mild cases, $14 \%$ were severe, and 5\% were crises (Wu and McGoogan, 2020). The death of positive covid-19 patients is also influenced by various congenital diseases. A sample of 355 COVID-19 positive patients who died in Italy has been reviewed in further detail. In the sample, $30 \%$ of patients had cardiovascular disease, $35.5 \%$ had diabetes, $20.3 \%$ had cancer and $9.6 \%$ had a history of stroke (Onder et al., 2020).

\section{Etiology}

Cov is a single positive strain RNA virus, has a capsule and does not have a segment with a crown-like appearance under the electron microscope (coronam is the Latin term for crown) due to the presence of protein. The Ortho-coronavirinae subfamily of the Coronaviridae family is classified into four genera: Alphacoronavirus 
(alphaCoV), Betacoronavirus (betaCoV), Deltaาcorona $\neg$ virus (deltaCov), and Gammacoronavirus (gammaCoV) (Cascella et al., 2020).

Human infection is caused by six coronaviruses and the 2019 novel coronavirus (SARS-CoV-2) is considered to be the seventh member of the coronavirus family to cause infection in humans. This virus belongs to the beta coronavirus group such as MERS coronavirus (MERS-CoV) and SARS coronavirus (SARS-CoV) which also cause disease in humans. (Rauf et al., 2020).

\section{Transmission}

Transmission is a central principle in the biology and epidemiology of infectious diseases, and for many viruses, animal-to-human transmission is an important step in pathogenesis. SARS-CoV-2 shares $96 \%$ of ribonucleic acid in common with the coronavirus isolated from Rhinolophus Sinicus in China's Yunnan province with origins traceable to the wholesale seafood market in Wuhan, China. Bats may be the original carriers of the virus with animals sold on the market by intermediate hosts (Xu et al., 2020).

Since the first cases of Covid-19 disease were linked to direct exposure to the Huanan Seafood Wholesale market in Wuhan, animal-to-human transmission is thought to be the main process. However, the latter case is not related to this process. Therefore, it can be concluded that the virus spreads from person to person, and people with symptoms are the source of Covid-19 transmission. There is a chance of transmission before symptoms develop, and a person who has no symptoms can transmit the virus. Isolation is the main step to stop the spread of this virus.

Like other respiratory pathogens, including flu and rhinovarus, transmission is known to occur via droplets from coughs and sneezes. Aerosol transmission is also possible in the case of exposure to increased aerosol concentrations in confined spaces. Analysis of data regarding the spread of SARS-CoV-2 in China seems to indicate that there was close contact between individuals. For the record, pre and asymptomatic individuals can contribute up to $80 \%$ of Covid-19 infections. The distribution is in fact only limited to family members, health workers and other close contacts (Cascella et al., 2020).

\section{Prevention}

Preventive action is the current strategy for limiting the spread of cases. Since the epidemic will increase as long as R0 is greater than 1 (covid-19 has an R0 of 2.2), control measures should focus on reducing the R0 value to less than 1 . WHO and other organizations have issued general recommendations to prevent the spread of covid-19 as follows:

a. Avoid close contact with subjects suffering from respiratory infections.

b. Wash hands frequently, especially after contact with infected people or their environment, before eating, after going outside.

c. A person with symptoms of an acute respiratory infection should keep their distance, cover coughs or sneezes with tissue or disposable clothing and wash their hands.

d. Must maintain a distance when in public places.

e. Use a mask if you have to go out of the house.

f. Exercise, eat nutritious food and get adequate rest. 
The most important strategies are to use a mask, wash your hands and / or use a portable hand sanitizer (handsanitazier). Avoid touching their face and mouth after interacting with a potentially contaminated environment and keeping their distance or avoiding crowds. (Cascella et al., 2020; Kratzel et al., 2020).

\section{METHODS}

Health education is carried out by means of lectures and discussions with the community using LCD media along with the distribution of lefleats and the distribution of masks by complying with health protocols such as participants using masks, maintaining distance and providing outdoor hand washing stations. The implementation of the activity begins with a pre-test, then continues with the provision of health education, and ends with a post-test measurement. The pre-test and post-test were carried out by implementing a health protocol with discipline. The activity was held on January 2, 2021 with the target of all members of the community in Batu Village, Malang District, Malang Regency.

\section{RESULTS}

The implementation of health education for the prevention of covid-19 transmission with the $3 \mathrm{M}$ movement (Wearing masks, maintaining distance, and washing hands) in Batu Village, Malang District, Malang Regency was attended by 20 participants. The activity runs smoothly, participants are able to understand the material provided where when the presenter evaluates the material that has been submitted, the participants are able to answer properly according to the questions asked. Participants have high enthusiasm for carrying out the $3 \mathrm{M}$ movement in everyday life, exercising, consuming nutritious food and getting adequate rest.

This knowledge improvement program begins with a pre-test to explore public knowledge about masks, maintaining distance and providing outdoor hand washing stations. The percentage of community knowledge during the pre-test showed that 8 people $(40 \%)$ had good knowledge, and the remaining 12 people $(60 \%)$ had poor knowledge. Post-test results obtained 16 people (80\%) have good knowledge, the rest, as many as 4 people (20\%) still have less knowledge.

\section{DISCUSSION}

Based on the results of health education regarding the prevention of Covid-19 transmission through the $3 \mathrm{M}$ movement (Wearing masks, maintaining distance, and washing hands), there has been an increase in public awareness and behavior in implementing health protocols in a disciplined manner. The government will continue to implement 3T (Tracing, Testing, Treatment) practices with the support of all levels of society. The application of $3 \mathrm{M}$ and $3 \mathrm{~T}$ is a package of efforts that cannot be separated to break the chain of transmission of COVID-19.

Based on some research, wearing a cloth mask can reduce the risk of transmitting COVID-19 by 45 percent. Better is wearing a surgical mask that can reduce the spread of the COVID-19 virus by up to 70 percent. Hand washing is $3 \mathrm{M}$ 's next step to reduce the risk of COVID-19 transmission by 35 percent. WHO recommends washing hands with soap/antiseptic for 20-30 seconds and applying the right steps. If under certain conditions, such as there is no water and soap or cannot use water and soap to clean hands, another solution is to use a liquid that is based on at least 60 percent alcohol such as hand sanitizer. The next implementation of $3 \mathrm{M}$ is to maintain a distance or social 
distancing with a minimum distance of 1 meter, including avoiding crowds. Discipline in complying with and implementing health protocols is the key as well as an effective non-medical vaccination to suppress the spread of Covid-19. Therefore, disciplined behavior is needed, both individually and collectively in general, which is carried out with full awareness to fight Covid-19 (Kratzel et al., 2020).

\section{CONCLUSIONS AND SUGGESTIONS}

Health education activities for the prevention of covid-19 transmission with the 3M movement (Wearing masks, maintaining distance, and washing hands) in Ngaglik District, Batu City, East Java, are effective in opening knowledge of public health knowledge (participants). Creating awareness among citizens to carry out the $3 \mathrm{M}$ movement. Creating self-awareness of residents of Ngaglik District, Batu City, East Java to adopt a clean and healthy lifestyle.

Health education activities for the prevention of covid-19 transmission with the $3 \mathrm{M}$ movement can run regularly and periodically. Health education activities for the prevention of covid-19 transmission with the 3M Ngaglik District movement, Batu City, East Java, added sports such as joint exercise while adhering to health protocols. Health education activities for the prevention of covid-19 transmission with the 3M Ngaglik District movement, Batu City, East Java were added to the distribution program for healthy food and multivitamins.

\section{ACKNOWLEDGMENTS}

The team thanked Prof. Bhisma Murti, dr, MPH, MSc, PhD who gave full support to this community service activity as well as to the village head of Ngaglik District and all village officials, residents of Ngaglik District, Batu City, East Java who provided time to participate in health education activities held until the event is over and a community service team that helps launch the activity to completion.

\section{REFERENCE}

Arima, Y., Kutsuna, S., Shimada, T., Suzuki, M., Suzuki, T., Kobayashi, Y., Tsuchihashi, Y., Nakamura, H., Matsumoto, K., Takeda, A., Kadokura, K., Sato, T., Yahata, Y., Nakajima, N., Tobiume, M., Takayama, I., Kageyama, T., Saito, S., Nao, N., ... Wakita, T. (2020). Severe Acute Respiratory Syndrome Coronavirus 2 Infection among Returnees to Japan from Wuhan, China, 2020. Emerging Infectious Diseases, 26(7), 1596-1600. https://doi.org/10.3201/eid2607. 200994

Cascella, M., Rajnik, M., Cuomo, A., Dulebohn, S. C., \& Di Napoli, R. (2020). Features, Evaluation and Treatment Coronavirus (COVID-19). In StatPearls. StatPearls Publishing. http://www.ncbi.nlm.nih.gov/pubmed/32150360

Guan, W., Ni, Z., Hu, Y., Liang, W., Ou, C., He, J., Liu, L., Shan, H., Lei, C., Hui, D. S. C., Du, B., Li, L., Zeng, G., Yuen, K.-Y., Chen, R., Tang, C., Wang, T., Chen, P., Xiang, J., ... Zhong, N. (2020). Clinical Characteristics of Coronavirus Disease 2019 in China. New England Journal of Medicine, 382(18), 1708-1720. https://doi.org/10.1056/NEJMoa2002032

Infeksi Emerging Kementerian Kesehatan RI. (n.d.). Retrieved February 14, 2021, from 
https://covid19.kemkes.go.id/protokol-covid-19/panduan-pencegahan-danpengendalian-corona-virus-disease-2019-covid-19-di-tempat-kerja-perkantorandan-industri-dalam-mendukung-keberlangsungan-usaha-pada-situasi-pandemi

Kementerian Kesehatan Republik Indonesia. (n.d.). Retrieved February 14, 2021, from https://www.kemkes.go.id/article/view/20012900002/Kesiapsiagaan-menghadapiInfeksi-Novel-Coronavirus.html

Kratzel, A., Todt, D., V'kovski, P., Steiner, S., Gultom, M., Thao, T. T. N., Ebert, N., Holwerda, M., Steinmann, J., Niemeyer, D., Dijkman, R., Kampf, G., Drosten, C., Steinmann, E., Thiel, V., \& Pfaender, S. (2020). Inactivation of Severe Acute Respiratory Syndrome Coronavirus 2 by WHO-Recommended Hand Rub Formulations and Alcohols. Emerging Infectious Diseases, 26(7), 1592-1595. https://doi.org/10.3201/eid2607.200915

Li, R., Pei, S., Chen, B., Song, Y., Zhang, T., Yang, W., \& Shaman, J. (2020). Substantial undocumented infection facilitates the rapid dissemination of novel coronavirus (SARS-CoV-2). Science, 368(6490), 489-493. https://doi.org/10. 1126/science.abb3221

Onder, G., Rezza, G., \& Brusaferro, S. (2020). Case-Fatality Rate and Characteristics of Patients Dying in Relation to COVID-19 in Italy. In JAMA - Journal of the American Medical Association (Vol. 323, Issue 18, pp. 1775-1776). American Medical Association. https://doi.org/10.1001/jama.2020.4683

Rauf, A., Abu-Izneid, T., Olatunde, A., Khalil, A. A., Alhumaydhi, F. A., Tufail, T., Shariati, M. A., Rebezov, M., Almarhoon, Z. M., Mabkhot, Y. N., Alsayari, A., \& Rengasamy, K. R. R. (2020). COVID-19 pandemic: Epidemiology, etiology, conventional and non-conventional therapies. In International Journal of Environmental Research and Public Health (Vol. 17, Issue 21, pp. 1-32). MDPI AG. https://doi.org/10.3390/ijerph17218155

WHO Coronavirus Disease (COVID-19) Dashboard | WHO Coronavirus Disease (COVID-19) Dashboard. (n.d.). Retrieved February 13, 2021, from https://covid19.who.int/

Wu, Z., \& McGoogan, J. M. (2020). Characteristics of and Important Lessons from the Coronavirus Disease 2019 (COVID-19) Outbreak in China: Summary of a Report of 72314 Cases from the Chinese Center for Disease Control and Prevention. In JAMA - Journal of the American Medical Association (Vol. 323, Issue 13, pp. 1239-1242). American Medical Association. https://doi.org/10.1001/jama. 2020.2648

Xu, J., Ma, X.-P., Bai, L., Wang, M., Deng, W., \& Ning, N. (2020). A systematic review of etiology, epidemiology, clinical manifestations, image findings, and medication of 2019 Corona Virus Disease-19 in Wuhan, China. Medicine, 99(42), e22688. https://doi.org/10.1097/MD.0000000000022688 